\title{
Committed Anchor Investment and IPO Survival -The Roles of Cornerstone and Strategic Investors ${ }^{\ddagger}$
}

\author{
Susanne Espenlaub* (Susanne.Espenlaub@mbs.ac.uk) \\ Arif Khurshed* (Arif.Khurshed@mbs.ac.uk) \\ Abdulkadir Mohamed** (Abdulkadir.Mohamed@ cranfield.ac.uk) \\ Brahim Saadouni* (Brahim.Saadouni@mbs.ac.uk)
}

\begin{abstract}
Recent U.S. policy encourages anchor investments to facilitate initial public offerings (IPO) and increase companies' access to external finance. As access to external funds relies on stocks remaining listed, we study anchor investors' impact on how long IPOs stay listed. We examine two types of anchor investors in Hong Kong: strategic and cornerstone investors, that are similar to U.S. anchor investors, but make varying levels of commitment at and post-IPO. We find that IPOs backed by more committed investors, with longer post-IPO commitments (lockups), stay listed longer. This suggests that the success of U.S. policies may require investors' commitment.
\end{abstract}

Keywords: Anchor investment, IPO, survival, share allocation, cornerstone investor, strategic investor, demand multiple, Hong Kong.

* Accounting \& Finance Division, Alliance Manchester Business School, University of Manchester, Booth Street West, Manchester M15 6PB; UK. Fax: ++44 1612754023.

**Cranfield Management School.

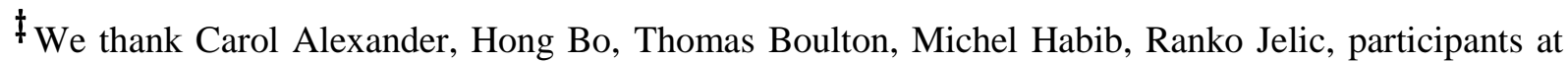
the International Finance and Banking Society (IFABS) conference (Oxford 2015), seminar participants at Essex, SOAS, Liverpool and Salford Universities for their helpful comments. 


\section{Introduction}

The recent U.S. policy initiatives contained in the so-called Jumpstart Our Business Startups (JOBS) Act allow companies planning a share listing to test the waters by gathering anchor investors' expressions of interest in the company shares before filing for an IPO with the Securities and Exchange Commission (SEC). The main policy objectives of the JOBS Act are ensuring firms' access to external finance with a view to encouraging real investment and job creation/preservation. Whether these policy objectives of the JOBS Act are likely to be achieved following a company's IPO relies on whether and how long the company shares remain listed on a stock market. The longer a company's stock remains listed on a stock market, the longer will the company have access to external capital. Anchor investors are commonly seen as facilitating the marketing of IPOs. We argue that they may also play a role in the post-IPO survival of share listings and examine the impact of anchor investors on the length of time stocks remain listed after an initial public offering (IPO). A recent study by Dambra, Field and Gustafson (2015) report that the introduction of the JOBS Act has had a positive impact on IPO volume. Our study adds to their findings on new listings by shedding light on the impact of anchor investors on how long such new listings remain listed.

Our study contributes to the current debate over the role of anchor investors. Although stock markets in the U.S. and elsewhere are increasingly encouraging the involvement of anchor investors prior to IPOs, little is known about the impact of anchor investors on IPO performance. In fact, the involvement of anchor investors has resulted in controversy in some IPOs, most notably the Royal Mail IPO in the UK. The flipping of shares by Royal Mail's cornerstone investors led to a policy review (Myners 2014) that highlighted the need for research on the issue.

We consider two types of committed anchor investors: strategic investors and cornerstone investors. These investors have played a prominent role in the Hong Kong IPO market since they first appeared in the wake of the East Asian Crisis of 1997. Strategic investors are typically dedicated long-term investors who derive additional cash flows from their investment in the firm, or who add value to the issuing firm, e.g., through their reputation and capabilities (Fuerst and Geiger 2003). In many cases, they are corporate investors that operate in the same industrial sector as the issuing company. For example, the IPO of Chalco, the 
leading Chinese aluminium producer, which gained a dual listing in New York and Hong Kong in December 2001, featured so-called strategic investors. Chalco's main strategic investor Alcoa, the World's largest aluminium producer, committed an investment just prior to the IPO that yielded Alcoa a $8 \%$ post-IPO stake in Chalco and agreed (and adhered) to a lock-up period of 30 months. The Chalco IPO prospectus outlines the plans for a joint venture between the two companies, and gives details of the appointment of an Alcoa executive as non-executive of Chalco.

By contrast, cornerstone investors are typically high net-worth, financial investors, such as institutional investors and very wealthy individuals, who seek purely financial returns and have varying investment horizons. Cornerstone investors have featured in several recent initial public offerings (IPOs) including those of Glencore (a Swiss-based multinational conglomerate that gained a dual listing in Hong Kong and London), the UK Automobile Association (AA), the Dutch NN Group Insurance and the Royal Mail.

Similar to U.S. anchor investors, these investors agree to invest in the IPO at the book building stage; but unlike in the U.S, these anchors investors enter into commitments both at the investment and post-IPO. Specifically, cornerstone and strategic investors enter into binding placing agreements with the issuing company and its advisors just prior to the release of the IPO prospectus whereby they agree to invest a specified monetary amount in the IPO. In return for this agreement, strategic and cornerstone investors are guaranteed to receive IPO shares for the full amount they pre-commit (even if the issue ends up being oversubscribed). Hong Kong listing rules require IPO firms and their underwriters to disclose full details relating to the allocation of shares to cornerstone and strategic investors. The guaranteed allocation of shares to these investors is also tied to post-IPO commitments as all cornerstone and strategic investors enter into lock-up agreements with IPO underwriters not to sell the shares they are allocated at the IPO during an agreed post-IPO lock-up period.

In the U.S., by contrast, anchor investors express their interests in investing in the IPO shares but these expressions of interest are not legally binding. There is no requirement on companies in the U.S. to disclose either the names or investments of anchor investors at the time of the IPO. And U.S. anchor investors do not enter to lockup agreements committing not to sell the shares they buy for a specified period after the IPO. 
Our analysis examines the impact of anchor-investor commitment on the length of time IPO stocks remain listed, and hence, the length of time the company continues to have access to external finance. Comparing the two types of committed anchor investors in Hong Kong, we find that strategic investors are significantly more committed than cornerstone investors both at the time of the IPO and particularly post-IPO. We find that longer post-IPO commitment, and greater involvement of strategic investors, including foreign investors, increases the length of time IPOs stock remain listed. Cornerstone investors, by contrast, appear to have little impact on IPO survival unless their post-IPO commitments are certified by a reputable underwriter.

Our results suggest that anchors investors play a role not just in helping companies achieve a listing but also in maintaining that listing post-IPO. However, the achievement of the latter, which is closely linked to the policy objective of the JOBS Act of ensuring company's access to finance over the longer-term, relies on the extent to which anchor investors are committed particularly post-IPO.

To the best of our knowledge, this is the first study to examine the impact of cornerstone and strategic investors on IPO survival performance. The absence of comparable research in most markets is due to the lack of data on anchor investor involvement in IPOs and on the allocation of shares in IPOs. The Hong Kong market is one of a handful of markets that require full disclosure of detailed information on overall investor demand for IPOs and the allocation of shares in the IPO to various investor groups, including retail, institutional, cornerstone and strategic investors.

Our paper also contributes to the literature on IPO survival (e.g., Hensler et al. 1997, Jain and Kini 2000). The length of time a stock remains listed post-IPO matters to issuers. Issuers trade off the high costs of an IPO against the benefits of being listed. The benefits of a stock-market listing (including the ability to raise new funds in the primary market and trade existing shares in a liquid secondary market) are only available as long as an IPO remains listed on the stock market. The continued listing of an IPO is also of significance to outside investors who seek financial returns from liquid investments, and even to stock markets, whose reputations suffer when there are high numbers of delistings. Our paper is related to studies that examine the impact on IPO survival of pre-IPO investors (such as venture capital investors) and other 
backers of the issuing firm providing pre-IPO certification (such as reputable underwriters or advisors). Our analysis shows that in addition to a direct effect of underwriter reputation on IPO survival, there is also an interaction effect suggesting that certification by reputable underwriters makes anchor-investor commitment more credible.

The rest of the paper is organized as follows: Section 2 provides an overview of the institutional background of the Hong Kong Stock Market, and Section 3 outlines the existing literature and our research objectives. Section 4 describes the data and methodology. Our empirical findings are discussed in Section 5, and Section 6 concludes the paper.

\section{Institutional Background}

This section describes the key regulatory features of the Hong Kong Stock Exchange that are relevant to IPO share allocation and the role of cornerstone and strategic investors. The IPO market of the Hong Kong Stock Exchange (HKEx) ranks highly internationally. It has proved to be resilient in terms of IPO volume while other IPO markets (including NASDAQ and NYSE) experienced sharp declines after the internet bubble (1999-2001) and following the Financial Crisis of 2008. Over the past decade, HKEx has consistently ranked amongst the world's top five IPO markets in terms of funds raised by IPO firms, and during each of the three years following the 2008 Financial Crisis (2009-2011), HKEx ranked first.

In terms of the allocation of shares to investors in an IPO, the HKEx combines clear rules with a significant degree of underwriter discretion. On the one hand, the allocation of shares to retail investors is subject to rules, including rules on the method of allocating shares to investors in oversubscribed IPOs. ${ }^{1}$ On the other hand, shares in the placing tranche are allocated to institutional, high-net-worth and corporate investors (both foreign and local) at the underwriter's discretion. Up-front, guaranteed allocations to cornerstone and strategic investors constitute a significant part of the placing tranche (McGuinness 2014).

\footnotetext{
${ }^{1}$ Underwriters are required to allocate to retail investors $30 \%$ of the issue if demand in the subscription tranche is between 15-50 times the initial allocation, $40 \%$ of the issue when such demand is between $50-100$ times the initial allocation, and $50 \%$ of the issue when demand is (over) 100 times the initial allocation. This standardized clawback provision does not apply to the additional shares that may be issued under the overallotment option $(\mathrm{OAO})$ where underwriters retain full discretion over share allocation.
} 
Unlike most markets, including the US and UK, the Hong Kong market requires full disclosure of information on the overall demand for IPO shares by investors, and on the allocation of shares in the IPO to various investor groups, including cornerstone and strategic investors as well as retail investors and institutions.

Cornerstone and strategic investors first appeared in 1997 in the wake of the Asian Financial Crisis. Cornerstone investors include high-net-worth entities. Amongst them are some of the wealthiest individuals in Hong Kong, such as Li Ka-shing, chairperson of Hutchison Whampoa (who was ranked top of the Forbes Asia List with a total wealth of US $\$ 32$ billion and Dr Lee Shau Kee, who leads Henderson Land and was ranked third with a wealth of about US 20 billion). ${ }^{2}$ Another group of cornerstone investors are state wealth funds (SWFs). For example, the Kuwait Investment Authority, the Qatar Investment Authority and Temasek (one of Singapore's SWFs) subscribed to about 36.6 percent of the just over 25.4 billion shares offered by the Agricultural Bank of China Ltd when it was listed in July 2010. Cornerstone investors also include companies, some of which are controlled by investors from Mainland China.

Strategic investors are major (corporate) customers and suppliers of the issuing company. They can also include companies operating in the same industry as the IPO firm. For example, BP Amoco Plc subscribed to 13.5 percent of the just over 16.78 billion shares offered by China Petroleum and Chemical Corporation when it was listed in October 2000. The German firm Siemens acquired about 5 percent of the shares offered by Shanghai Electric Company Ltd that was listed in April 2005. More recently, strategic investors have also included private equity providers and investment banks.

Cornerstone and strategic investors enter into contractual placing agreements with the issuing company and its advisors, guaranteeing them a share allocation at the IPO amounting to a predefined dollar amount. This is done just prior to the release of the prospectus and before the number of shares set aside for subscription to retail and institutional investors is finalized. The listing rules require IPO firms and their underwriters to disclose the full details relating to the allocation of shares to these privileged (cornerstone and strategic) investors. The guaranteed allocation of shares is often tied to commitments (lock-up agreements) made by the investor

\footnotetext{
${ }^{2}$ See the ranking at http://www.forbes.com/hong-kong-billionaires/list/.
} 
to the IPO underwriters not to sell the allocated shares during an agreed lock-up period. Our analysis below shows that strategic investors normally commit to lock-up periods of between 6 and 36 months, with an average of 12 months, while cornerstone investors are typically locked up for periods ranging from 6 to 12 months (with the average being 6 months). This is consistent with existing evidence on lockup periods reported in McGuinness (2012, 2014). McGuinness examines Hong Kong IPOs issued during 2005-2009, he finds a significant positive relation between cornerstone backing and IPO valuations. However, he finds no impact of strategic investors on IPO valuation or performance, most likely due to the small number of strategic-backed IPOs in his sample.

\section{Literature and Research Questions}

There is a substantial body of literature on the survival of newly listed stocks mostly focusing on North America. Their reported failure rates range widely due to differences between markets, sample periods, and stock characteristics (e.g., penny or high-tech stocks). E.g., U.S. estimates of five-year survival rates range from 9 to 47 percent. The seminal study by Hensler et al. (1997) investigates the relation between IPO survival rates and firm and issue characteristics using a hazard model and finds that survival rates are positively related to firm age and size, IPO initial returns and insider ownership. Jain and Kini (1999) examine the probability of surviving post-IPO and that firm size at the time of the IPO, pre-IPO operating performance and underwriter reputation are positively related to IPO survival. Jain and Kini (2000) examine whether venture capital (VC) involvement improves the survival profile of IPO firms. Their findings indicate that the probability of post IPO survival is significantly positively affected by $\mathrm{VC}$ backing and the prestige of the investment bank leading the underwriting syndicate as well as by other factors likely to benefit from VC involvement such as road show success and analyst following. Ahmed and Jelic (2014) report evidence for a positive relation between survival rates and lock-up periods in U.K. IPOs.

We expect two possible effects of committed anchor investors on IPO survival: a selection effect and a treatment (or value-added) effect. The selection effect may arise from the superior abilities of informed investors to identify high-quality firms prior to their IPOs. Associated with this is the certification hypothesis (Megginson and Weiss 1991, Jain and Kini 2000), suggesting that reputable informed investors (such as pre-IPO venture capital backers) can 
certify the quality of the issuing firm. Alternatively, or in addition, we expect a treatment (or value-added) effect due to the post-IPO monitoring and nurturing of the issuing company by its long-term investors that adds value, or rather "survivability", to the company post-IPO.

As cornerstone investors seek financial returns often in the short to medium term, we expect that they impact post-IPO performance through selection or certification. By contrast, strategic investors by definition aim to derive or add non-financial value from long-term investments in the issuing firm. Hence, we expect these investors to (mainly) impact post-IPO performance through nurturing such as post-IPO monitoring or sharing of expertise and networks. On the other hand, strategic investors may also have a selection effect: given their long-term strategic interests, they are likely to invest specifically in IPOs they expect to survive for longer.

We model several dimensions of the impact of cornerstone and strategic investors. The first avenue of influence is through the size of the share allocation to each of these investor types in the IPO. Larger allocations may suggest a greater commitment by investors before the IPO and a greater influence on the issuing company post-IPO. Pre-IPO commitment and post-IPO alignment of interests is also captured by the length of the investors' lock-up period. We expect strategic investors to have longer lock-up periods than the more short-term-oriented cornerstone investors. Also, we expect strategic investors' lock-up periods to have a stronger impact on post-IPO performance.

\section{Data and Methodology}

We use a comprehensive sample of 903 IPOs issued on the Main Board of the Hong Kong Stock Exchange during 1990-2010-Q2. ${ }^{3}$ The list of IPO firms, their listing dates and industry sectors are obtained from the Hong Kong Stock Exchange Annual Fact Book. IPO prospectuses and allocation data are from the Hong Kong Stock Exchange. Data on firm characteristics (including market capitalization, issue proceeds) are extracted from the prospectuses. In a few cases where data was initially missing, we use additional data from the Hong Kong regulator, the Securities and Futures Commission. Each IPO is tracked until 31 December 2013 to determine whether it is delisted or not. Post-1999 delisting dates are

\footnotetext{
3 Our sample excludes introductions of stocks that were previously traded on another market.
} 
collected from the Hong Kong Stock Exchange Annual Fact Book; pre-1999 delisting dates are hand-collected from the Hong Kong Public Library. We identify IPOs with cornerstone or strategic investors from the IPO prospectuses. Data relating to these investors is mostly from the prospectuses (investor names, numbers and lock-up agreements), the Hong Kong Stock Exchange (allocation details), and internet searches (on the investors; countries of origin). Offer price is obtained from the prospectus, and first-day closing stock prices from DataStream.

Following existing literature (e.g., Espenlaub et al. 2012), we use survival analysis to investigate the determinants of the survival rates. In our study, IPOs are "right censored" if they have not yet been delisted and remain listed until the end of the study period (31 December 2013). We define survivors as stocks of firms that continue to be traded on the HKEx. We distinguish between delisting due to M\&A and delisting due to other, negative reasons, because the impact on investors is typically far more adverse in the case of negative delisting, e.g. liquidations, than in M\&As. We examine the robustness of our results by alternately classifying all M\&As as failures (non-survivors), or by treating all or some M\&A stocks as "censored" survivors.

We apply Kaplan-Meier method to estimate the survival rates for each post-IPO month for the full sample and for various subsamples. To test whether IPOs in different groups, backed by strategic investors, cornerstone investors or un-backed IPOs, share the same Kaplan-Meier survival curves, we use the log rank test (e.g., Kleinbaum and Klein 1996, pp557-63), a largesample chi-square test. We estimate the Accelerated Failure Time (AFT) model and Cox proportional hazard model. Prior studies (Hensler et al. 1997, Jain and Kini 2000, Espenlaub et al. 2012) use the AFT method that allows the impact of the independent variables on the survival time to vary over the post-IPO period, depending on the length of time since listing. The AFT model is typically expressed in terms of a log-linear function with respect to time (see e.g. Hensler et al. 1997; Bradburn et al. 2003):

$$
\operatorname{Ln}\left(\mathrm{T}_{\mathrm{j}}\right)=\beta_{0}+\beta_{1} X_{1}+\ldots \beta_{\mathrm{p}} X_{p}+\varepsilon_{\mathrm{j}}
$$

Specifically, we estimate the following model: 


$$
\begin{aligned}
\operatorname{Ln}\left(T_{j}\right) & =\beta_{0}+\beta_{1} \text { Strategic }+\beta_{2} \text { Cornerstone }+\beta_{3} \text { Demand multiple }+\beta_{4} \text { Insider Ownership } \\
& +\beta_{5} \text { Family Control }+\beta_{6} \text { Instit. Allocation }+\beta_{7} \text { Age }+\beta_{87} \text { Size }+\beta_{9} \text { Initial return } \\
& +\beta_{10} \text { Proceeds }+\beta_{11} \text { Pre }- \text { IPO net profits }+\beta_{12} \text { Pre }- \text { IPO Sales }+\beta_{13} H-\text { Share } \\
& +\beta_{14} \text { Reputable Underwriter }+ \text { Industry }+ \text { Year }+\varepsilon_{j}
\end{aligned}
$$

where $\operatorname{Ln}(\mathrm{Tj})$ is the natural logarithm of the survival time or time to failure, and the independent variables are as follows: Strategic (and similarly Cornerstone) is measured as (i) a binary variable, (ii) the average lock-up period of these investors in the IPO, (iii) the number of these investors involved in the IPO, (iv) the ratio of foreign to local strategic (or cornerstone) investors and (v) the proportion of shares in the IPO allocated to these investor. Demand multiple is the oversubscription rate for shares at the time of the IPO; Insider ownership is the percentage of insider ownership at the time of the IPO; Family control is a dummy variable taking a value of one if the IPO firm is family controlled and zero otherwise; Instit. Allocation is the proportion of shares in the IPO allocated to institutional investors; Age is the number of years from establishment until the IPO; Size is market capitalization at the IPO price; Initial return is the difference between the first-day closing and offer price as a percentage of the offer price; Proceeds is IPO proceeds in million Hong Kong dollars. PreIPO net profits is the operating income in the year before the year of the IPO; Pre-IPO sales is sales before the year of the IPO; $H$-share is a dummy variable that equals 1 if the IPO firm is incorporated in mainland China but listed in Hong Kong and zero otherwise; Reputable underwriter is a dummy variable taking a value of 1 if an IPO is underwritten by reputable underwriters as measured by the number of IPOs and proceeds, and zero otherwise. ${ }^{4} \mathrm{We}$ control for industry and year fixed effects. ${ }^{5}$

As the AFT is a parametric model, it is necessary to specify the distribution of the baseline survival function. We use the likelihood ratio or Wald tests to determine the appropriate distribution in the case of nested models, such as comparing the Weibull against the exponential distribution, or the gamma against the Weibull or lognormal distribution. The Akaike Information Criterion (AIC) is the appropriate test for choosing the best-fitting model in the case of non-nested models, such as between the log-logistic and the lognormal distributions. The AIC is defined as

\footnotetext{
${ }^{4}$ See definitions of variables in Appendix I.

${ }^{5}$ There is no evidence of multicollinearity; see Appendix V for the correlation matrix.
} 


$$
A I C=-2 \operatorname{Ln} L+2(k+c)
$$

where $\mathrm{L}$ is the maximized value of the likelihood function, $\mathrm{k}$ is the number of model covariates and $\mathrm{c}$ is the number of model-specific distributional parameters. Both the lognormal and log-logistic models have two distributional parameters $(c=2)$. The AIC test shows that the lognormal distribution has a lower AIC value than the log-logistic model, and hence we select the lognormal distribution.

In the AFT model, the exponential of the coefficient is an 'acceleration factor' also known as the time ratio: The effect of an independent variable (covariate) is to extend or shrink the length of survival by a constant relative amount equal to the time ratio. If the time ratio is greater than one, an increase in the covariate increases survival time; while with a time ratio below one, an increase in the covariate decreases survival time (Bradburn et al. 2003). By comparison, in the Cox Model, the acceleration factor is the hazard ratio. If the hazard ratio is above one, then an increase in the covariate increases the failure rate (note here the dependent variable is failure risk, not the survival time), while a hazard ratio of less than one suggests that an increase in the covariate decreases the failure rate.

\section{Results}

Table I shows the distribution of IPOs, and of surviving and delisted stocks, in our sample of 903 Hong Kong IPOs listed between 1990 and 2010 (Q2). The numbers of IPOs per year are broadly stable over this period, unlike in US IPO markets. By the end of 2013, 107 of our sample IPOs are delisted due to a merger or acquisition (M\&A) and 73 IPOs are delisted for other reasons (including suspension and withdrawal). By IPO year, the percentage of delisted IPOs ranges from 4 percent (for the most recent IPOs) to 35 percent (for some of the earliest IPO cohorts). There is some difference in terms of M\&A and other delistings, with the latter becoming more frequent over recent years. As outlined above, we allow for alternate ways of classifying M\&A delistings (as either failures or censored non-survivors).

\section{[TABLE I HERE]}


In Table II, we first examine the prevalence of backing of IPOs by either cornerstone or strategic investors. ${ }^{6}$ We observe a substantial presence of strategic and cornerstone investors with 202 IPOs backed by strategic investors and 179 IPOs backed by cornerstone investors. These figures amount to 33 and 30 percent, respectively, of the 607 Hong Kong IPOs issued during 1997-2010. In our analysis, we measure the strength of the post-IPO commitment of cornerstone and strategic investors by the length of their lockup periods. We find that strategic investors are on average locked up for 12 months with a maximum of 36 months. For example, the lockup period of strategic investor Alcoa in the Chalco IPO (described in the Introduction) is 30 months, close to the maximum. By contrast, cornerstone investors are on average locked up for just 6 months with a maximum of 12 months. The differences in mean and median lockup periods between cornerstone and strategic investors are both economically and statistically significant. We conclude that strategic investors are significantly more committed post-IPO than cornerstone investors.

An indicator of investor commitment at the time of the IPO is the proportion of the share issue taken up by the two investor types with a larger allocation suggesting greater commitment. On average, strategic investors take up 28 percent of a given IPO. This aggregate allocation is shared among an average of 4 strategic investors per issue. The cornerstone investors of a given IPO on average take up 20 percent of the shares on offer at the IPO, and this aggregate cornerstone take-up is shared among an average of 3 cornerstone investors per issue. The difference between strategic and cornerstone investors in terms of their mean aggregate IPO allocations is statistically significant at the 10 percent level. This leads us to conclude that strategic investors are more committed than cornerstone investors at the IPO.

Finally, we examine the influence of foreign investors among the two investor types. As reported above, there is an average number of 4 strategic and 3 cornerstone investors per IPO, and of these we find that about 1 in 3 investors is foreign while the remaining 2 are locallybased investors. The difference between strategic and cornerstone investors in terms of the ratio of foreign-to-local investors is minor, although the difference in medians is statistically

\footnotetext{
${ }^{6}$ The figures reported in Table I (and the subsequent estimations) exclude 13 IPOs that received backing by both cornerstone and strategic investors. This subsample is too small to yield meaningful insights when analyzed separately.
} 
significant at 10 percent. In conclusion, there is some evidence that foreign investors play a slightly greater role among strategic investors than among cornerstone investors.

Next, we examine underwriter reputation. There is some evidence that reputable underwriter are associated with less risky IPOs (Carter and Manaster 1990). Following Carter and Manaster, underwriter reputation is typically measured using tombstone rankings in U.S. studies. As no comparable tombstones are available in Hong Kong, we measure reputation by market share: reputable underwriters are those in the top quartile in terms of both numbers and proceeds of IPOs they bring to the market during the three years prior to the IPO year. We find that reputable underwriters are involved in one quarter of strategic-backed IPOs but in only 11 percent of cornerstone-backed IPOs. Certification of IPOs by reputable underwriters may be more important to strategic investors due to their longer investment horizons. By contrast, cornerstone investors appear to rely less on underwriter certification. In fact, cornerstone-backed IPOs appear to be associated with less reputable underwriters. In conclusion, we find that strategic investors' commitment, particularly their post-IPO commitment through lockup agreements with underwriters, is more commonly certified by reputable underwriters than cornerstone investors' commitments. Certification by reputable underwriters is likely to render these investors' commitments more credible and effective. We examine this conjecture further below.

Next, we compare and contrast other characteristics of IPOs backed by strategic investors with those backed by cornerstone investors. Focusing on statistically significant differences between the two subsamples, we find that strategic-backed IPOs are less oversubscribed than cornerstone-backed IPOs and have lower initial returns. The allocation of IPO shares to institutional investors (excluding cornerstone or strategic investors) is somewhat lower in strategic-backed IPOs (52 percent) than in cornerstone-backed IPO (60 percent), but this difference is not statistically significant.

Comparing the characteristics of issuing companies, we find that strategic-backed IPOs are issued by smaller yet older companies. Cornerstone-backed IPOs have significantly larger market capitalization and higher proceeds than strategic-backed IPOs but pre-IPO sales and pre-IPO net profits are not significantly different between the two subsamples. Strategicbacked IPO companies are on average 20 years old at the time of going public, while the age 
of cornerstone-backed companies is (statistically) significantly lower at just 16 years. Just under half of strategic-backed IPOs are issued by family firms, while there are no family firms at all in the cornerstone-backed subsample of IPOs. This suggests that family-owned IPO firms prefer strategic investors that enter into long-term commitments to cornerstone investors with short-term investment horizons. Strategic-backed IPOs are less likely to be Mainland Chinese companies issuing $\mathrm{H}$ shares.

\section{[TABLE II HERE]}

Breaking down the strategic and cornerstone-backed subsamples into stocks that survive and those that fail by the end of 2013, we find that only 12 IPOs (6 percent) of the 202 strategicbacked IPOs fail, compared to 28 (15.6 percent) of the 179 cornerstone-backed IPOs, and 46 (20.4 percent) of the 226 unbacked IPOs. These figures clearly suggest an association between committed anchor-investor backing and IPO survival. To examine the impact of the committed investor types on survival more rigorously, we compute the non-parametric Kaplan-Meier survival rates of strategic- and cornerstone-backed IPOs relative to IPOs without such backing. Table III shows cumulative Kaplan-Meier survival rates by the end of the first, third and fifth post-IPO year for IPOs listed during 1997-2010(Q2). Using log rank tests, we conclude that the Kaplan-Meier survival rates of strategic-backed IPOs are statistically significantly higher than those of cornerstone-backed IPOs and of unbacked IPOs (at significance levels above 5 percent).

Examining survival rates for each of the 14 IPO year cohorts (or vintages), we find that almost all cohorts of strategic-backed IPOs have 100 percent survival rates over the first postIPO year. The exception is the 2001 vintage with a survival rate of 95 percent. Over the medium term (three years post-IPO), we find 100 percent survival of strategic-backed IPOs for eight of the 14 IPO year cohorts, with the lowest survival rate of 92 percent observed for the 2001 cohort. After five years post-IPO, we still find 100 percent survival for four of the 12 cohorts of strategic-backed IPOs. Note, we observe five post-IPO years only for 12 IPO year cohorts (compared to 14 cohorts for which we can observe survival over one and three postIPO years) because there are fewer than five years between the final IPO year and the end of our study period (end 2013) The lowest five-year survival rate for strategic-backed IPOs is 89 
percent (corresponding to a delisting or failure rate of 11 percent) observed for the 2008 cohort.

Cornerstone-backed IPOs have equally high survival rates over the first post-IPO year. Even IPOs without the backing of committed (strategic or cornerstone) investors have relatively high one-year survival rates (for most year cohorts except in 1998 and 2000). However, differences emerge and widen over subsequent years of listing. Three-year survival rates are higher for strategic-backed IPOs than cornerstone-backed IPOs. Eight (four) of the 14 year cohorts of IPOs backed by strategic (cornerstone) investors have 100 percent survival after three years. Of the remaining six year cohorts (where strategic-backed IPOs have less than 100 percent survival), strategic backed IPOs have higher survival rates than cornerstonebacked IPOs in four of these six cohorts. Compared to unbacked IPOs, strategic-backed IPOs have higher (or the same) three-year survival rates in each year cohort. The difference becomes even clearer when we focus on five year survival rates. We find that IPOs backed by strategic investors have higher survival rates than either cornerstone-backed IPOs or unbacked IPOs in each of the year cohorts. Overall, we find that the positive impact of strategic investors (and to a lesser extent, of cornerstone investors) on survival grows stronger the longer we track companies post-IPO.

\section{[TABLE III HERE]}

Our univariate analysis so far suggests an association between the involvement of strategic and cornerstone investors in IPOs and post-IPO survival. Next, we conduct a multivariate analysis to examine the impact of strategic and cornerstone investors on IPO survival after controlling for a range of company and IPO characteristics and other known determinants of IPO survival. First, we estimate an AFT model that controls for company and issue characteristics including the age of the IPO firm, size as measured by market capitalization, pre-IPO net profits, pre-IPO sales, insider ownership, IPO initial returns, proceeds, institutional share allocation, and the level of oversubscription of the IPO (known as the demand multiple). In this AFT model we treat observations that are delisted due to an M\&A as censored survivors. As the baseline distribution of the model, we choose the log-normal distribution based on the AIC (as outlined in the methodology section above). 
In Model I, we measure strategic and cornerstone backing using a binary indicator and find that backing by strategic investors significantly increases the time to delisting. The impact of strategic investors is both economically and statistically significant. The exponential of the statistically significant positive strategic-investor coefficient (0.382) is the time ratio (1.466). This time ratio suggests that the presence of a strategic investor increases survival times by 46.6 percent (i.e., a one-unit increase in the strategic-investor variable increases survival times by a multiple of 1.466). IPO backing by cornerstone investors, by contrast, plays no significant role (given its statistically insignificant coefficient). We also find that share allocations to institutional investors are statistically significant, but only at 10 percent conventional level. This raises the question of why up-front involvement by strategic investors has a significant impact on IPO survival, while cornerstone backing and allocations to institutional investors pursuant to the wider IPO allocation do not.

To address this question we need to understand the underlying factors that drive the impact of strategic investors on IPO survival. One important aspect is likely to be the lock-up agreements entered into by strategic and cornerstone investors. We estimate a series of survival models that (instead of binary indicators) use four continuous measures of the involvement, and commitment, of strategic and cornerstone investors. First, in Model II, we examine the impact of lock-up agreements. In principle, investors with (longer) lock-up agreements will have a greater incentive to ensure a company stays listed at least until the end of the lock-up period. Thus, we expect that strategic investors (with an average 12-month lock-up period) will be associated with longer survival times than cornerstone investors (with an average 6-month lock-up period). Compared to strategic and cornerstone investors, we expect a weaker or no effect on IPO survival of institutional investors that are allocated shares in the IPO without a lock-up period.

Next, in Model III, we measure investor impact using the number of investors of either type backing a given IPO. We expect that more investors of a given type will increase their impact on the IPO firm, including on the firm's propensity to delist. Model IV examines the role of foreign investors (as opposed to local investors) of either type. Foreign investors may have less influence due to their remoteness from the market (and from the firm in the case of Hong Kong based companies). They may also derive different levels of benefits from the company remaining listed (and possibly bear a different share of the costs of listing). Foreign investors' 
incentives to ensure the firm remains listed may therefore differ from those of domestic investors. Finally, in Model V, we examine the proportions of shares issued in the IPO that are allocated to strategic or cornerstone investors. Taking up a larger share of the issue may signify greater investor commitment at the IPO, and hence impact IPO survival.

The results of Model II, shown in Table IV, show that the length of strategic investors' lockup periods significantly increases the time to delisting. This is consistent with our expectation that greater investor commitment post-IPO through longer lockup periods leads to longer survival times. By contrast, the lock-up periods of the less committed cornerstone investors do not significantly impact survival times.

In Model III, we find that larger numbers of strategic investors have a statistically significant, positive impact on survival times: More strategic investors in an IPO result in the stock remaining listed longer. By contrast, the effect of cornerstone investors is insignificant, that is, the number of cornerstone investors backing an issue does not matter to IPO survival. Focusing on the ratio of foreign to local investors in Model III, we find that the presence of more foreign strategic investors does in fact significantly delay delisting. Rather than being more remote and less committed, this result suggests greater commitment, or greater credibility of commitment, by foreign as compared to local investors. For cornerstone investors, by contrast, the impact of the ratio of foreign to local investors on survival times is statistically insignificant.

Model V shows that the proportions of shares allocated to strategic or cornerstone investors at IPOs have no statistically significant impact on survival times. We also examine the impact of the dollar amounts invested by strategic and cornerstone investors in a given IPO, and find qualitatively similar, insignificant results (not reported). This suggests that it is not the amount invested nor the percentage stake taken up by strategic investors, but purely their contractual commitments at and after the IPO, that drive their impact on IPO survival.

Finally, we examine whether anchor investors' commitments are more credible if these commitments are certified by reputable underwriters. Specifically, anchor investors' post-IPO commitments revolve around the lockup agreements they entered into with IPO underwriters. Post-IPO, underwriters may allow locked up investors to sell shares prior to the end of their lockup periods. In the U.S., such early release from lockup periods is becoming increasingly 
common in IPOs and seasoned equity offerings (SEOs). Hence, we expect that anchor investors' lockup agreements are more credible if they are entered into with underwriters that have more reputation capital at stake.

Models VI and VII in Table IV include interaction terms between anchor-investor variables and underwriter reputation to test whether underwriter reputation increases the committed anchor-investor effect on IPO survival times. In this case, we expect a positive coefficient on the interaction term. Consistent with this expectation, in Model VI, we find statistically significant, positive coefficients of the binary indicators of both strategic- and cornerstoneinvestor backing. In fact, we find that the direct effect of strategic-investor backing is 28.2 percent increase of survival time (given the time ratio of 1.282), while the indirect interaction effect of strategic-investor backing with reputable underwriter certification is 1.5 times the direct effect. IPOs backed by strategic investors whose commitment is certified by reputable underwriters have 42 percent longer survival times than strategic-backed IPOs without underwriter certification. The direct effect of cornerstone investors remains insignificant as in the previous analyses, but cornerstone-backing that is certified by reputable underwriters (who are involved in just 11 percent of cornerstone-backed IPOs as shown in Table II above) does significantly increase survival times by 10 percent (time ratio 1.099).

Focusing on underwriter certification of anchor investors' lockup agreements in Model VII, we find statistically significant positive coefficients on the interaction terms of underwriter reputation and lockup length for both strategic and cornerstone investors. We conclude that underwriter certification renders investor commitments more credible for both strategic investors and their relatively less committed counterparts, cornerstone investors. Our results suggest that the positive effect on IPO survival of strategic investors' post-IPO commitment is increased by reputable underwriter certification. However, as shown by the positive direct effect (the significant positive coefficient) of strategic-investor lockup periods, strategic investors' post-IPO commitment is credible even without underwriter certification. By contrast, cornerstone investors' post-IPO commitment is only credible if it is certified by reputable underwriters. ${ }^{7}$

\footnotetext{
${ }^{7}$ Our results remain quantitatively the same when we use a sample of IPOs listed between 1997 and 2010. Please see the results in Appendix IV.
} 


\section{[TABLE IV HERE]}

\section{Robustness of the results}

We examine the robustness of our results in several ways. First, we treat delistings due to M\&As as censored survivors rather than as "failures" (as in Table IV above). This means that our analysis focuses on explaining delistings due to reasons that are more clearly unfavourable to investors (suspensions, withdrawals and other delistings) than M\&As, which may not be detrimental to (target) shareholders. See the discussion of whether M\&As should be treated as failures or censored survivors in Espenlaub et al. (2012). The results shown in Table V, corresponding to Table IV, are qualitatively unchanged. We find that strategic investors have a significant positive impact on survival times (at the 1 percent level of significance) irrespective of whether their influence is measured as a binary indicator, the number of such investors, the ratio of foreign to local strategic investors, or the lock-up periods of strategic investors.

\section{[TABLE V HERE]}

As a further robustness check and for comparison with other studies, we also estimate the Cox proportional hazard model, applied, for example, by Carpentier and Suret (2011). Unlike the AFT model, the Cox model makes no assumption about the distribution of the baseline parameter. The dependent variable in the Cox model measures the risk of delisting (failure) as opposed to the survival time that is measured in the AFT model. In the Cox model, the marginal effect of an independent variable is measured by the so-called hazard ratio, calculated as the exponential of the coefficient from the Cox model (see, e.g., and Klein 1996). A positive coefficient implies a hazard ratio greater than one, suggesting that an increase in the covariate increases the failure rate. Similarly, a negative coefficient implies a hazard ratio of less than one, indicating that an increase in the covariate reduces the failure rate. The corresponding measure of the marginal effect in the AFT model is the so-called "time ratio". The time ratio is calculated as the exponential of the AFT coefficient (Bradburn et al. 2003). As a consequence, we expect that a given independent variable with a positive sign (and a time ratio above one) in the AFT model will have a negative coefficient (and a hazard ratio of less than one) in the Cox model. Bearing in mind this difference in the signs of 
the coefficients, the results reported in Table VI are qualitatively the same as those reported for the AFT models in Tables IV and V above.

\section{[TABLE VI HERE]}

In Table VII, we control for endogeneity and selection effects. Our results for strategic investors above may be due to strategic investors' selection of companies that are likely to survive longer, or due to omitted variables determining both strategic investor backing and survival. To disentangle selection and treatment effects, we use a propensity score model to match IPOs backed by cornerstone or strategic investors with non-backed IPOs, by age, initial returns, market capitalization, proceeds, pre-IPO sales and pre-IPO profit. Panel A shows the mean and median values for cornerstone-investor-backed IPOs and a non-backed matched sample excluding IPOs backed by strategic investors. Panel B shows the results of strategicinvestor-backed IPOs and a matched sample of non-cornerstone-backed companies. In Panels $\mathrm{A}$ and $\mathrm{B}$ the characteristics of the matched samples in terms of means and medians are not statistically different from the IPOs backed by either cornerstone or strategic investors.

Panel C of Table VII shows the AFT results, where M\&As are treated as failures (Model I) and censored (Model II). The results of Model I in Table VII are comparable to those of Model I in Table IV. The strategic-investor indicator is positive and statistically significant, while the indicator of cornerstone backing is statistically insignificant. These results suggest that backing by strategic investors has a positive treatment effect on the survival of IPOs. In other words, our results suggest that strategic investors 'add survivability' to IPO firms through their post-IPO commitment to monitoring and sharing of expertise and networks, etc. In Model II of Table VII, we alternately treat M\&As as censored survivors; and find results that are consistent with Model I in that the presence of strategic investors adds survivability to IPO firms. The impacts of other (control) variables are similar to the results reported in Tables IV and V, respectively. It is possible that strategic or cornerstone investors do not select their IPOs companies randomly. This may induce a sample selection bias. To address this concern we estimate the inverse mills ratios and include these as additional control variables in the AFT model. Model III, show the results controlling for such possible sample selection bias. It is evident that sample selection is not a concern in our estimates, since both inverse mills ratios (strategic/cornerstone) are not significant at any conventional level. Our results that 
IPOs with strategic investors have higher survival times than those backed by cornerstone remain robust.

Overall, the results suggest that the presence and commitment of strategic investors has a positive impact on the survival of IPOs post listing, while the presence of less committed cornerstone investors does not.

\section{[TABLE VII HERE]}

\section{Conclusion}

This study examines the impact of anchor investors' commitment on IPO survival, focusing on two types of committed anchor investors: strategic and cornerstone investors. The Hong Kong IPO market provides detailed data on IPO share allocations and on the placing agreements between issuers and anchor (strategic/cornerstone) investors that are not available in most other markets. Based on a comprehensive sample of Hong Kong IPOs between 1990 and 2010, we find that strategic and cornerstone investors participate in a significant number of IPOs (about 33 and 30 percent, respectively). We find that, compared to cornerstone investors, strategic investors make stronger commitments at the IPO and particularly postIPO. The lock-up periods of strategic investors are significantly longer (on average 12 months) than those of cornerstone investors (averaging 6 months). Strategic investors' commitments (through their lockup agreements) are more likely to be certified by reputable underwriters than those of cornerstone investors. We find that the backing of the IPO by more committed anchor investors (strategic investors) significantly increases how long IPO stocks remain listed. Specifically, we estimate that strategic-investor backing increases listing (or survival) times by between 39 to 75 percent. The level of strategic investors' post-IPO commitment, as reflected in the length of their lockup periods, significantly increases the length of time the IPO remains listed. The numbers of strategic investors backing an IPO, and the proportion of foreign relative to local strategic investors, also significantly increase how long IPOs remain listed. The impact of strategic-investor backing is even stronger when their (post-IPO) commitments are certified by reputable underwriters. The less committed anchor investors (cornerstone investors), by contrast, have no significant direct impact on IPO survival times. It is only if cornerstone investors' commitments are certified by reputable 
underwriters that they have a (comparatively small) significant impact on survival times. Controlling for selection effects, we find that our results are driven by treatment effects, that is, by the value that strategic investors add to IPO companies by strategic investors through their monitoring, expertise and access to networks.

In sum, our results indicate that the presence of committed anchor investors at and after the IPO, and the strength of their commitment are significant determinants of IPO survival. Our results are important for issuers, investors and practitioners, and to stock markets and policy makers promoting the involvement of anchor investors. The success of policy initiatives such as the U.S. JOBS Act, that promote anchor investors to facilitate IPOs, may achieve their aim of ensuring companies' longer-term access to external finance by ensuring or increasing anchor investors' commitment.

Our paper highlights not only the significance of anchor investors' commitment, but also the need for disclosure of anchor investors' involvement in IPOs. Our results show that knowledge of anchor-investor involvement, along with data on IPO share allocation, allows investors to identify IPOs that are more likely to remain listed for longer. This finding raises serious concerns over the lack of disclosure of allocation data in most IPO markets. 


\section{References}

Ahmed, Wasim, and Jelic, Ranko, 2014, Lockup Agreements and Survival of UK IPOs. Journal of Business Finance and Accounting 41, 714-74.

Bradburn, Michael, Clark, Tony, Love, Sanders, and Altman, Douglas, 2003, Survival analysis part II: multivariate data analysis-an introduction to concepts and methods, British Journal of Cancer 89, 431-436.

Carpentier, Cécile, and Suret, Jean-Marc, 2011, The survival and success of penny stock IPOs: Canadian evidence, Small Business Economics 36, 101-121.

Carter, Richard and Manaster, Steven, 1990, Initial Public Offerings and Underwriter Reputation. Journal of Finance 45, 1045-1067.

Dambra, Michael, Field Laura and Gustafson, Matthew, 2015, The jobs act an IPO volume: Evidence that disclosure costs affects the IPO decision. Journal of Financial Economics 1, 121-143.

Espenlaub, Susanne, Khurshed, Arif and Mohamed, Abdulkadir, 2012, IPO survival in a reputational market. Journal of Business Finance and Accounting 39, 427-463.

Fuerst, Oren and Geiger, Uri, 2003, From Concept to Wall Street: A complete guide to entrepreneurship and venture capital. New York/London, Financial Times Prentice Hall.

Hensler, Douglas, Rutherford, Ronald, and Springer, Thomas, 1997, The survival of initial public offerings in the aftermarket, Journal of Financial Research 20, 93-110.

Jain, Bharat and Kini, Omesh, 1999, The life cycle of initial public offering firms. Journal of Business Finance and Accounting 26, 1281-1307.

Jain, Bharat, and Kini, Omesh, 2000, Does the presence of venture capitalists improve the survival profile of IPO firms? Journal of Business Finance \& Accounting 27, 1139-1176.

Kleinbaum, David and Klein, Mitchel 1996, Survival analysis: A self-learning text, Springer Verlag: New York.

McGuinness, Paul, 2012, The role of 'cornerstone' investors and the Chinese state in the relative underpricing of state- and privately controlled IPO firms, Applied Financial Economics 22, 15291551. 
McGuinness, Paul, 2014, IPO firm value and its connection with cornerstone and wider signalling effects, Pacific-Basin Finance Journal 27, 138-162.

Megginson, William, and Weiss, Kathleen, 1991, Venture capitalist certification in initial public offerings. Journal of Finance, 46, 879-903.

Myners, 2014, An independent review for the secretary of state for business, innovation \& skills: https://www.gov.uk/government/uploads/system/uploads/attachment_data/file/388660/bis-141300-myners-independent-review-for-secretary-of-state-for-business-ipos-and-bookbuilding-infuture-hm-government-primary-share-disposals.pdf. 
Table I: Distribution of IPO firms by year of listing

This table shows the distribution of IPO firms listed on the Hong Kong Stock Exchange between 1990 and the end of June 2010. The sample is divided into failures due to M\&As and due to other reasons for delisting up to the end of December 2013.

\begin{tabular}{cccccc}
\hline $\begin{array}{c}\text { IPO } \\
\text { Year }\end{array}$ & Full sample & $\begin{array}{c}\text { M\&A } \\
\text { Delistings }\end{array}$ & $\begin{array}{c}\text { M\&A } \\
\text { Delisting (\%) }\end{array}$ & $\begin{array}{c}\text { Other } \\
\text { Delistings }\end{array}$ & $\begin{array}{c}\text { Other } \\
\text { Delisting (\%) }\end{array}$ \\
\hline $\mathbf{1 9 9 0}$ & 13 & 4 & 30.77 & 0 & 0.00 \\
$\mathbf{1 9 9 1}$ & 48 & 12 & 25.00 & 2 & 4.17 \\
$\mathbf{1 9 9 2}$ & 54 & 13 & 24.07 & 5 & 9.26 \\
$\mathbf{1 9 9 3}$ & 63 & 15 & 23.81 & 7 & 11.11 \\
$\mathbf{1 9 9 4}$ & 50 & 10 & 20.00 & 7 & 14.00 \\
$\mathbf{1 9 9 5}$ & 24 & 4 & 16.67 & 3 & 12.50 \\
$\mathbf{1 9 9 6}$ & 44 & 7 & 15.91 & 5 & 11.36 \\
$\mathbf{1 9 9 7}$ & 78 & 8 & 10.26 & 3 & 3.85 \\
$\mathbf{1 9 9 8}$ & 28 & 3 & 10.71 & 2 & 7.14 \\
$\mathbf{1 9 9 9}$ & 28 & 3 & 10.71 & 2 & 7.14 \\
$\mathbf{2 0 0 0}$ & 37 & 6 & 16.22 & 1 & 2.70 \\
$\mathbf{2 0 0 1}$ & 30 & 3 & 10.00 & 3 & 10.00 \\
$\mathbf{2 0 0 2}$ & 48 & 8 & 16.67 & 5 & 10.42 \\
$\mathbf{2 0 0 3}$ & 37 & 2 & 5.41 & 2 & 5.41 \\
$\mathbf{2 0 0 4}$ & 31 & 2 & 6.45 & 1 & 3.23 \\
$\mathbf{2 0 0 5}$ & 52 & 1 & 1.92 & 1 & 1.92 \\
$\mathbf{2 0 0 6}$ & 52 & 1 & 1.92 & 2 & 3.85 \\
$\mathbf{2 0 0 7}$ & 77 & 2 & 2.60 & 9 & 11.69 \\
$\mathbf{2 0 0 8}$ & 27 & 2 & 7.41 & 4 & 14.81 \\
$\mathbf{2 0 0 9}$ & 58 & 1 & 1.72 & 8 & 13.79 \\
$\mathbf{2 0 1 0}(\mathbf{Q} 2)$ & 24 & 0 & 0.00 & 1 & 4.17 \\
Total & $\mathbf{9 0 3}$ & $\mathbf{1 0 7}$ & $\mathbf{1 2 \%}$ & $\mathbf{7 3}$ & $\mathbf{8 \%}$ \\
\hline & & & & & \\
\hline
\end{tabular}




\section{Table II: Descriptive Statistics and Univariate Analysis}

The table shows descriptive statistics for the two subsamples of IPOs backed by either cornerstone or strategic investors. The presence of cornerstone investors (and similarly of strategic investors) is measured as (i) the proportion of shares in the IPO allocated to these investors, (ii) the number of these investors involved in the IPO, (iii) the ratio of foreign to local cornerstone (or strategic) investors, and (iv) the average lock-up period of these investors in the IPO. Instit. Allocation is the proportion of shares in the IPO allocated to institutional shareholders. Demand multiple is the oversubscription rate for shares at the time of the IPO. Insider ownership is the percentage of insider ownership at the time of the IPO. Family control is a dummy variable taking a value of one if the IPO firm is family controlled and zero otherwise. Age is the number of years from establishment until the IPO. Initial return is the difference between the first-day closing and offer price as a percentage of the offer price. Size is market capitalization at the IPO price (in million Hong Kong dollars). Proceeds is IPO proceeds in million Hong Kong dollars. Pre-IPO sales is sales before the year of the IPO. Pre-IPO net profits is the operating income in the year before the year of the IPO. $\mathrm{H}$-share is a dummy variable that equals 1 if the IPO firm is incorporated in the Chinese mainland but listed in Hong Kong and zero otherwise. Reputable underwriter is a dummy variable taking a value of 1 if an IPO is underwritten by reputable underwriters as measured by the number of IPOs and proceeds, and zero otherwise. $* * * * *$, and $*$ indicate significance at $1 \%, 5 \%$, and $10 \%$ respectively.

\begin{tabular}{lccccccccccc}
\hline & \multicolumn{2}{c}{ Mean } & \multicolumn{2}{c}{ Median } & \multicolumn{2}{c}{ STD } & & Min & Max \\
& Corner & Strat. & Corner & Strat. & Corner & Strat. & Corner & Strat. & Corner & Strat. \\
\hline Corner/Strat_investors' lock-up (months) & $6.00^{* * *}$ & 12.00 & $6.00^{* * *}$ & 12.00 & 3.40 & 5.70 & 6.00 & 6.00 & 12.00 & 36.00 \\
Corner/Strategic investors' IPO alloacation & $0.202^{*}$ & 0.284 & 0.190 & 0.200 & 0.116 & 0.145 & 0.031 & 0.038 & 0.625 & 0.764 \\
Number of Corner/Strat_investors per IPO & 3.00 & 4.00 & 2.00 & 3.00 & 3.00 & 4.00 & 1.00 & 1.00 & 9.00 & 11.00 \\
Corner/Strat_investors (foreign to local) & 0.628 & 0.592 & $0.529^{*}$ & 0.573 & 0.403 & 0.401 & 0.000 & 0.00 & 1.714 & 1.571 \\
Instit. Allocation & 0.60 & 0.52 & 0.55 & 0.48 & 0.25 & 0.22 & 0.00 & 0.00 & 0.92 & 0.80 \\
\hline
\end{tabular}


Table II continued

\begin{tabular}{|c|c|c|c|c|c|c|c|c|c|c|}
\hline Demand multiple & $127.02 * *$ & 67.46 & $35.20 * *$ & 18.70 & 110.20 & 58.53 & 6.00 & 3.19 & 441.68 & 234.59 \\
\hline Insider ownership & 0.71 & 0.77 & 0.75 & 0.70 & 0.05 & 0.05 & 0.65 & 0.61 & 0.87 & 0.81 \\
\hline Family control & $0.00 * * *$ & 0.49 & 0.00 & 0.00 & 0.00 & 0.51 & 0.00 & 0.00 & 0.00 & 1.00 \\
\hline Age & $15.90^{*}$ & 20.10 & $12.65^{*}$ & 16.00 & 11.70 & 14.80 & 5.54 & 7.00 & 45.87 & 58.00 \\
\hline Initial return & $0.180^{*}$ & 0.100 & $0.11^{*}$ & 0.06 & 0.24 & 0.14 & -0.19 & -0.11 & 0.75 & 0.43 \\
\hline Size (m) & $6220.00 * *$ & 4789.40 & $4150.00 * *$ & 3730.00 & 9240.00 & 9040.80 & 204.00 & 184.08 & 26100.00 & 20097.00 \\
\hline Proceeds (m) & $2140.00 *$ & 1968.80 & $1180.00 *$ & 1085.60 & 2250.00 & 2070.00 & 51.00 & 59.40 & 6520.00 & 5998.40 \\
\hline Pre-IPO sales (m) & 5056.00 & 4940.29 & 4328.00 & 4228.95 & 3081.00 & 3010.49 & 97.00 & 94.78 & 9238.00 & 9026.58 \\
\hline Pre-IPO net profits & 393.00 & 388.61 & 248.00 & 245.23 & 36.00 & 35.60 & 20.00 & 19.78 & 1086.00 & 1073.88 \\
\hline H-shares & $0.18^{*}$ & 0.120 & 0.00 & 0.00 & 0.42 & 0.27 & 0.00 & 0.00 & 1.00 & 1.00 \\
\hline Reputable underwriter & $0.109 * *$ & 0.245 & 0.00 & 0.00 & 0.191 & 0.254 & 0.00 & 0.00 & 1.00 & 1.00 \\
\hline No of obs & 179 & 202 & & & & & & & & \\
\hline
\end{tabular}




\section{Table III: Survival rates}

This table shows the survival rates for all IPOs listed between 1997 and 2010, by IPO year and by type of investor backing the IPO (i.e., cornerstone- and strategic-investor backed IPOs, and unbacked IPOs). Each IPO firm is tracked over one year, three years and five years post listing. For firms listed in 2009 and 2010, only oneyear and three-year survival rates are reported.

\begin{tabular}{|c|c|c|c|c|c|c|c|c|c|c|c|c|}
\hline \multirow[b]{2}{*}{$\begin{array}{l}\text { IPO } \\
\text { year }\end{array}$} & \multirow[b]{2}{*}{ Obs } & \multicolumn{3}{|c|}{$\begin{array}{c}\begin{array}{c}\text { Strategic } \\
\text { investors }\end{array} \\
\text { Cum. survival rate } \\
\end{array}$} & \multicolumn{4}{|c|}{$\begin{array}{c}\text { Cornerstone investors } \\
\text { Cum. survival rate } \\
\end{array}$} & \multicolumn{4}{|c|}{$\begin{array}{c}\text { Unbacked IPOs } \\
\text { Cum. survival rate }\end{array}$} \\
\hline & & $\begin{array}{c}1 \\
\mathbf{Y r}\end{array}$ & $\begin{array}{c}3 \\
\text { Yrs } \\
\end{array}$ & $\begin{array}{c}5 \\
\text { Yrs } \\
\end{array}$ & Obs & $\begin{array}{c}1 \\
\mathbf{Y r} \\
\end{array}$ & $\begin{array}{c}3 \\
\text { Yrs } \\
\end{array}$ & $\begin{array}{c}5 \\
\text { Yrs } \\
\end{array}$ & Obs & $\begin{array}{c}1 \\
\text { Yr } \\
\end{array}$ & $\begin{array}{c}3 \\
\text { Yrs } \\
\end{array}$ & $\begin{array}{c}5 \\
\text { Yrs } \\
\end{array}$ \\
\hline 1997 & 9 & 100 & 100 & 100 & 6 & 100 & 100 & 100 & 63 & 100 & 96 & 91 \\
\hline 1998 & 8 & 100 & 100 & 100 & 7 & 100 & 100 & 100 & 13 & 96 & 88 & 86 \\
\hline 1999 & 11 & 100 & 100 & 100 & 9 & 100 & 98 & 95 & 8 & 100 & 96 & 92 \\
\hline 2000 & 13 & 100 & 100 & 100 & 10 & 100 & 96 & 92 & 14 & 97 & 93 & 90 \\
\hline 2001 & 17 & 95 & 92 & 90 & 13 & 96 & 94 & 89 & 0 & N/A & N/A & N/A \\
\hline 2002 & 12 & 100 & 99 & 97 & 8 & 100 & 95 & 91 & 28 & 100 & 95 & 92 \\
\hline 2003 & 8 & 100 & 100 & 98 & 9 & 100 & 98 & 96 & 20 & 100 & 96 & 93 \\
\hline 2004 & 7 & 100 & 96 & 94 & 19 & 100 & 97 & 93 & 5 & 100 & 96 & 92 \\
\hline 2005 & 21 & 100 & 100 & 99 & 16 & 100 & 100 & 98 & 15 & 100 & 98 & 96 \\
\hline 2006 & 24 & 100 & 97 & 95 & 20 & 100 & 95 & 88 & 8 & 100 & 97 & 94 \\
\hline 2007 & 31 & 100 & 97 & 93 & 29 & 100 & 95 & 90 & 17 & 100 & 97 & 88 \\
\hline 2008 & 9 & 100 & 93 & 89 & 5 & 100 & 93 & 82 & 13 & 100 & 66 & 66 \\
\hline 2009 & 23 & 100 & 100 & N/A & 20 & 100 & 100 & N/A & 15 & 100 & 89 & N/A \\
\hline 2010 & 9 & 100 & 100 & N/A & 8 & 100 & 92 & N/A & 7 & 100 & 95 & N/A \\
\hline
\end{tabular}




\section{Table IV: AFT results (M\&A are failures)}

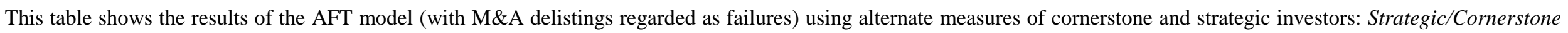

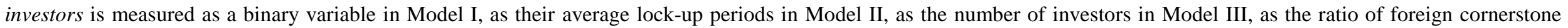

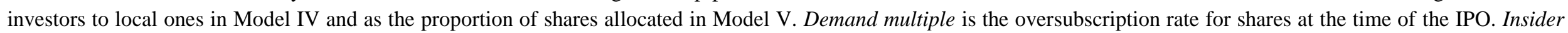

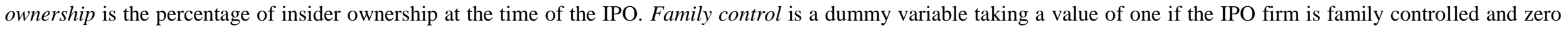

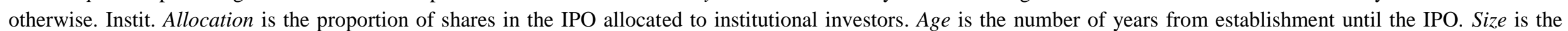

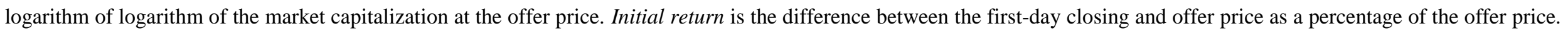

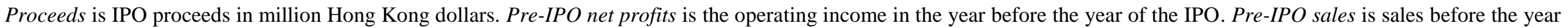

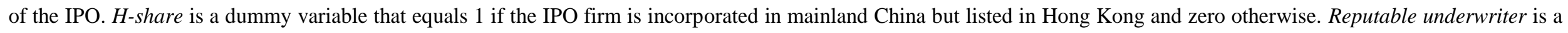

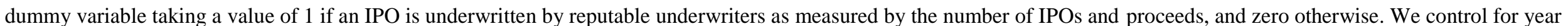
and industry in the regressions. $* * * * *$, and $*$ indicate significance at $1 \%, 5 \%$, and $10 \%$ respectively.

\begin{tabular}{|c|c|c|c|c|c|c|c|c|c|c|c|c|c|c|}
\hline \multirow[t]{2}{*}{ M\&As as failures } & \multicolumn{2}{|c|}{$\begin{array}{c}\text { Model I } \\
\text { Binary }\end{array}$} & \multicolumn{2}{|c|}{$\begin{array}{l}\text { Model II } \\
\text { Lock-up }\end{array}$} & \multicolumn{2}{|c|}{$\begin{array}{l}\text { Model III } \\
\text { Number }\end{array}$} & \multicolumn{2}{|c|}{$\begin{array}{c}\text { Model IV } \\
\text { Foreign-local }\end{array}$} & \multicolumn{2}{|c|}{$\begin{array}{c}\text { Model V } \\
\text { Allocations } \\
\end{array}$} & \multicolumn{2}{|c|}{$\begin{array}{c}\text { Model VI } \\
\text { Binary }\end{array}$} & \multicolumn{2}{|c|}{$\begin{array}{c}\text { Model VII } \\
\text { Lock-up }\end{array}$} \\
\hline & Coeff & TR & Coeff & TR & Coeff & TR & Coeff & TR & Coeff & TR & Coeff & TR & Coeff & TR \\
\hline Strategic investor & $0.382 * * *$ & 1.466 & $0.275^{* * *}$ & 1.316 & $0.401 * * *$ & 1.494 & $0.548 * * *$ & 1.730 & $0.311^{*}$ & 1.365 & $0.248 * *$ & 1.282 & $0.220 * *$ & 1.245 \\
\hline Strategic investor $\mathrm{x}$ Reput underwriter & & & & & & & & & & & $0.348 * * *$ & 1.416 & $0.561 * * *$ & 1.752 \\
\hline Cornerstone investor & 0.196 & 1.216 & 0.049 & 1.050 & 0.067 & 1.069 & 0.115 & 1.122 & 0.193 & 1.213 & 0.054 & 1.055 & 0.141 & 1.151 \\
\hline Cornerstone investor $\mathrm{x}$ Reput underwriter & & & & & & & & & & & $0.094 *$ & 1.099 & $0.065^{*}$ & 1.067 \\
\hline Demand multiple & $0.090 *$ & 1.094 & $0.085 * *$ & 1.088 & $0.088 * *$ & 1.092 & $0.033 * *$ & 1.034 & $0.032 *$ & 1.033 & 0.071 & 1.074 & 0.061 & 1.063 \\
\hline Insider ownership & $0.257 * *$ & 1.293 & $0.153 * *$ & 1.165 & $0.147 * *$ & 1.159 & $0.165^{* *}$ & 1.180 & $0.166^{* * *}$ & 1.180 & $0.215^{* *}$ & 1.240 & $0.154 * *$ & 1.167 \\
\hline Family control & $0.241 *$ & 1.273 & $0.327 * *$ & 1.386 & $0.376^{* *}$ & 1.457 & $0.269 * *$ & 1.309 & $0.260^{* *}$ & 1.297 & $0.287^{*}$ & 1.333 & $0.337^{*}$ & 1.401 \\
\hline Instit. allocation & $0.484 *$ & 1.623 & $0.296 * *$ & 1.344 & $0.479 * *$ & 1.615 & $0.263 * *$ & 1.301 & $0.264 * *$ & 1.303 & $0.373 *$ & 1.452 & $0.327 *$ & 1.387 \\
\hline
\end{tabular}


Table IV continues

\begin{tabular}{|c|c|c|c|c|c|c|c|c|c|c|c|c|c|c|}
\hline Age & $0.136^{*}$ & 1.145 & 0.075 & 1.078 & 0.072 & 1.074 & 0.031 & 1.031 & 0.025 & 1.025 & $0.119^{*}$ & 1.126 & 0.051 & 1.053 \\
\hline Size & $0.063 * * *$ & 1.065 & $0.035 * * *$ & 1.036 & $0.034 * * *$ & 1.034 & $0.037 * * *$ & 1.038 & $0.037 * * *$ & 1.038 & $0.089 * *$ & 1.093 & $0.056 * *$ & 1.058 \\
\hline Initial return & $0.394 * *$ & 1.551 & 0.013 & 1.013 & 0.024 & 1.025 & 0.012 & 1.012 & 0.012 & 1.012 & $0.176^{*}$ & 1.193 & 0.018 & 1.018 \\
\hline Proceeds & $0.064^{* *}$ & 1.066 & $0.038 * * *$ & 1.038 & $0.036 * * *$ & 1.037 & $0.040 * * *$ & 1.038 & $0.038 * * *$ & 1.038 & $0.067 * *$ & 1.069 & $0.038 * *$ & 1.039 \\
\hline Pre-IPO net profits & $0.084 *$ & 1.088 & 0.041 & 1.042 & $0.012 *$ & 1.012 & $0.031 *$ & 1.032 & $0.034^{*}$ & 1.035 & 0.064 & 1.066 & 0.043 & 1.044 \\
\hline Pre-IPO sales & $0.102 *$ & 1.107 & 0.010 & 1.010 & 0.015 & 1.015 & 0.009 & 1.009 & 0.015 & 1.009 & 0.076 & 1.079 & 0.070 & 1.073 \\
\hline H-shares & 0.089 & 1.093 & 0.042 & 1.043 & 0.074 & 1.076 & 0.024 & 1.024 & 0.026 & 1.027 & 0.080 & 1.084 & 0.049 & 1.051 \\
\hline Reput underwriter & $0.141 * *$ & 1.152 & 0.019 & 1.019 & 0.017 & 1.017 & 0.045 & 1.046 & $0.050 *$ & 1.051 & $0.137 * *$ & 1.146 & $0.073 *$ & 1.075 \\
\hline Industry & $\mathrm{Y}$ & & $\mathrm{Y}$ & & $\mathrm{Y}$ & & $\mathrm{Y}$ & & $\mathrm{Y}$ & & $\mathrm{Y}$ & & $\mathrm{Y}$ & \\
\hline Year & $\mathrm{Y}$ & & $\mathrm{Y}$ & & $\mathrm{Y}$ & & $\mathrm{Y}$ & & $\mathrm{Y}$ & & $\mathrm{Y}$ & & $\mathrm{Y}$ & \\
\hline Constant & -0.721 & & 1.127 & & 1.304 & & 1.512 & & 1.387 & & -0.641 & & 0.511 & \\
\hline Pseudo R-square & 0.171 & & 0.182 & & 0.181 & & 0.180 & & 0.184 & & 0.151 & & 0.140 & \\
\hline No of obs. & 903 & & 903 & & 903 & & 903 & & 903 & & 903 & & 903 & \\
\hline
\end{tabular}




\section{Table V: AFT results (M\&A are censored survivors)}

This table shows the results of an AFT model (where M\&A delistings are treated as censored survivors) using alternate measures of cornerstone and strategic investors: Strategic/Cornerstone investors is measured as a binary variable in Model I, as their average lock-up periods in Model II, as the number of investors in Model III, as the ratio of foreign cornerstone investors to local ones in Model IV and as the proportion of shares allocated in Model V. Demand multiple is the oversubscription rate for shares at the time of the IPO. Insider ownership is the percentage of insider ownership at the time of the IPO. Family control is a dummy variable taking a value of one if the IPO firm is family controlled and zero otherwise. Instit. Allocation is the proportion of shares in the IPO allocated to institutional investors. Age is the number of years from establishment until the IPO. Size is the logarithm of logarithm of the market capitalization at the offer price. Initial return is the difference between the first-day closing and offer price as a percentage of the offer price. Proceeds is IPO proceeds in million Hong Kong dollars. Pre-IPO net profits is the operating income in the year before the year of the IPO. Pre-IPO sales is sales before the year of the IPO. H-share is a dummy variable that equals 1 if the IPO firm is incorporated in mainland China but listed in Hong Kong and zero otherwise. Reputable underwriter is a dummy variable taking a value of 1 if an IPO is underwritten by reputable underwriters as measured by the number of IPOs and proceeds, and zero otherwise. We control for year and industry in the regressions. ***, **, and * indicate significance at $1 \%, 5 \%$, and $10 \%$ respectively.

\begin{tabular}{|c|c|c|c|c|c|c|c|c|c|c|}
\hline \multirow[t]{2}{*}{ (M\&As treated as censored) } & \multicolumn{2}{|c|}{$\begin{array}{l}\text { Model I } \\
\text { Binary }\end{array}$} & \multicolumn{2}{|c|}{$\begin{array}{l}\text { Model II } \\
\text { Lock-up }\end{array}$} & \multicolumn{2}{|c|}{$\begin{array}{l}\text { Model III } \\
\text { Number }\end{array}$} & \multicolumn{2}{|c|}{$\begin{array}{c}\text { Model IV } \\
\text { Foreign-local }\end{array}$} & \multicolumn{2}{|c|}{$\begin{array}{c}\text { Model V } \\
\text { Allocations }\end{array}$} \\
\hline & Coeff & TR & Coeff & TR & Coeff & TR & Coeff & TR & Coeff & TR \\
\hline Strategic investor & $0.325 * * *$ & 1.385 & $0.280 * * *$ & 1.324 & $0.320 * * *$ & 1.377 & $1.257 * * *$ & 3.516 & 0.114 & 1.121 \\
\hline Cornerstone investor & 0.189 & 1.209 & 0.016 & 1.016 & 0.016 & 1.016 & 0.106 & 1.112 & 0.037 & 1.038 \\
\hline Demand multiple & $0.047 * *$ & 1.048 & 0.082 & 1.085 & 0.075 & 1.077 & 0.080 & 1.084 & 0.080 & 1.084 \\
\hline Insider ownership & $0.230 * * *$ & 1.258 & $0.213 * * *$ & 1.238 & $0.213^{* * *}$ & 1.237 & $0.212 * *$ & 1.237 & $0.234 * * *$ & 1.264 \\
\hline Family control & 0.027 & 1.027 & 0.188 & 1.207 & 0.109 & 1.115 & 0.165 & 1.179 & 0.131 & 1.140 \\
\hline Instit. allocation & $0.189 *$ & 1.208 & 0.011 & 1.011 & 0.122 & 1.130 & 0.123 & 1.131 & 0.028 & 1.028 \\
\hline Age & 0.104 & 1.110 & 0.019 & 1.019 & 0.019 & 1.019 & 0.019 & 1.019 & 0.023 & 1.024 \\
\hline Size & $0.061 * * *$ & 1.063 & $0.048 * * *$ & 1.049 & $0.049 * * *$ & 1.049 & $0.048 * * *$ & 1.049 & $0.048 * * *$ & 1.048 \\
\hline Initial return & 0.116 & 1.123 & 0.020 & 1.020 & 0.029 & 1.030 & 0.013 & 1.013 & 0.015 & 1.015 \\
\hline Proceeds & $0.063 * *$ & 1.065 & $0.051 * * *$ & 1.053 & $0.051 * * *$ & 1.053 & $0.051 * * *$ & 1.053 & $0.051^{* * *}$ & 1.053 \\
\hline Pre-IPO net profits & 0.060 & 1.061 & 0.017 & 1.018 & 0.010 & 1.010 & 0.019 & 1.019 & 0.003 & 1.003 \\
\hline Pre-IPO sales & 0.064 & 1.067 & 0.015 & 1.015 & 0.016 & 1.016 & 0.015 & 1.015 & 0.019 & 1.020 \\
\hline H-shares & 0.173 & 1.189 & 0.174 & 1.191 & 0.150 & 1.162 & 0.182 & 1.199 & 0.195 & 1.215 \\
\hline Reput underwriter & $0.102 *$ & 1.108 & 0.070 & 1.072 & 0.118 & 1.125 & 0.068 & 1.070 & 0.231 & 1.260 \\
\hline Industry & $\mathrm{Y}$ & & $\mathrm{Y}$ & & $\mathrm{Y}$ & & $\mathrm{Y}$ & & $\mathrm{Y}$ & \\
\hline Year & $\mathrm{Y}$ & & $\mathrm{Y}$ & & $\mathrm{Y}$ & & $\mathrm{Y}$ & & $\mathrm{Y}$ & \\
\hline Constant & -1.872 & & 1.408 & & 1.420 & & 1.414 & & 1.417 & \\
\hline Pseudo R-square & 0.188 & & 0.186 & & 0.188 & & 0.182 & & 0.179 & \\
\hline No of obs & 903 & & 903 & & 903 & & 903 & & 903 & \\
\hline
\end{tabular}




\section{Table VI: Cox model}

This table shows the results of a Cox model in which M\&A delistings are regarded as failures (Model I) and censored survivors (Model II): Strategic investors is a dummy equal to 1 if strategic investors invested in the company and zero otherwise. Cornerstone investors is a dummy equal to 1 if cornerstone investors invested in the company and zero otherwise. Demand multiple is the oversubscription rate for shares at the time of the IPO. Insider ownership is the percentage of insider ownership at the time of the IPO. Family control is a dummy variable taking a value of one if the IPO firm is family controlled and zero otherwise. Instit. Allocation is the proportion of shares in the IPO allocated to institutional investors. Age is the number of years from establishment until the IPO. Size is the logarithm of logarithm of the market capitalization at the offer price. Initial return is the difference between the first-day closing and offer price as a percentage of the offer price. Proceeds is IPO proceeds in million Hong Kong dollars. Pre-IPO net profits is the operating income in the year before the year of the IPO. Pre-IPO sales is sales before the year of the IPO. $\mathrm{H}$-share is a dummy variable that equals 1 if the IPO firm is incorporated in mainland China but listed in Hong Kong and zero otherwise. Reputable underwriter is a dummy variable taking a value of 1 if an IPO is underwritten by reputable underwriters as measured by the number of IPOs and proceeds, and zero otherwise. We control for year and industry in the regressions. ***, **, and $*$ indicate significance at $1 \%, 5 \%$, and $10 \%$ respectively.

\begin{tabular}{lcccc}
\hline \multirow{2}{*}{ Variables } & \multicolumn{2}{c}{ Model I : M\&A as failure } & \multicolumn{2}{c}{ Model II: M\&A as censored } \\
\cline { 2 - 5 } & Coeff & Haz-ratio & Coeff & Haz-ratio \\
\hline & & & & \\
Strategic investor & $-0.435^{* * *}$ & 0.647 & $-0.987^{* *}$ & 0.373 \\
Cornerstone investor & -0.231 & 0.729 & -0.151 & 0.860 \\
Demand multiple & $-0.015^{*}$ & 0.985 & $-0.149^{*}$ & 0.861 \\
Insider ownership & $-0.364^{* *}$ & 0.695 & $-0.373^{* * *}$ & 0.688 \\
Family control & -0.136 & 0.873 & -0.219 & 0.804 \\
Instit. allocation & -0.102 & 0.903 & -0.315 & 0.730 \\
Age & -0.048 & 0.953 & -0.172 & 0.842 \\
Size & $-0.161^{*}$ & 0.852 & $-0.186^{* * *}$ & 0.830 \\
Initial return & $-0.144^{*}$ & 0.866 & $-0.197^{*}$ & 0.821 \\
Proceeds & $-0.162^{* *}$ & 0.850 & $-0.192^{* * *}$ & 0.826 \\
Pre-IPO net profits & -0.030 & 0.970 & $-0.085^{*}$ & 0.918 \\
Pre-IPO sales & -0.012 & 0.988 & -0.091 & 0.913 \\
H-shares & -0.082 & 0.921 & -0.163 & 0.849 \\
Reput underwriter & $-0.259^{* *}$ & 0.772 & -0.175 & 0.840 \\
Industry & $\mathrm{Y}$ & & $\mathrm{Y}$ & \\
Year & $\mathrm{Y}$ & & $\mathrm{Y}$ & \\
& & & & \\
Pseudo R-square & & & 0.136 & \\
No of obs & 0.129 & & 903 & \\
\hline
\end{tabular}




\section{Table VII: Propensity score matching and selection}

This table shows the results of propensity score matching. Panel A shows the univariate analysis of the IPOs backed by cornerstone investors and the matched sample. Panel B shows the results for the strategic investors and the matched sample. Panel C shows the multivariate analysis using the AFT model. Model I shows the results when M\&As are treated as failures, while Model II shows the results when M\&As are censored. Model III shows the results of sample selection. Strategic investors is a dummy equal to 1 if strategic investors invested in the company and zero otherwise. Cornerstone investors is a dummy equal to 1 if cornerstone investors invested in the company and zero otherwise. Demand multiple is the oversubscription rate for shares at the time of the IPO. Insider ownership is the percentage of insider ownership at the time of the IPO. Family control is a dummy variable taking a value of one if the IPO firm is family controlled and zero otherwise. Instit. Allocation is the proportion of shares in the IPO allocated to institutional investors. Age is the number of years from establishment until the IPO. Size is the logarithm of logarithm of the market capitalization at the offer price. Initial return is the difference between the first-day closing and offer price as a percentage of the offer price. Proceeds is IPO proceeds in million Hong Kong dollars. Pre-IPO net profits is the operating income in the year before the year of the IPO. Pre-IPO sales is sales before the year of the IPO. H-share is a dummy variable that equals 1 if the IPO firm is incorporated in mainland China but listed in Hong Kong and zero otherwise. Reputable underwriter is a dummy variable taking a value of 1 if an IPO is underwritten by reputable underwriters as measured by the number of IPOs and proceeds, and zero otherwise. We control for year and industry. $* * * * *$, and $*$ indicate significance at $1 \%, 5 \%$, and $10 \%$ respectively.

\begin{tabular}{|c|c|c|c|c|}
\hline \multirow[t]{2}{*}{ Panel A: Univariate } & \multicolumn{2}{|c|}{ Cornerstone } & \multicolumn{2}{|c|}{ Matched sample } \\
\hline & Mean & Median & Mean & Median \\
\hline Age & 15.9 & 12.65 & 15.26 & 12.14 \\
\hline Initial return & 0.18 & 0.11 & 0.17 & 0.10 \\
\hline Size (m) & 6220 & 4150 & 6157 & 4050 \\
\hline Proceeds (m) & 2140 & 1180 & 2011 & 1109 \\
\hline Pre-IPO sales (m) & 5056 & 4328 & 4954 & 4241 \\
\hline Pre-IPO net profits & 393 & 248 & 381 & 240 \\
\hline No of obs. & 179 & & 110 & \\
\hline \multirow[t]{2}{*}{ Panel B: Univariate } & \multicolumn{2}{|c|}{ Strategic } & \multicolumn{2}{|c|}{ Matched sample } \\
\hline & Mean & Median & Mean & Median \\
\hline Age & 20.1 & 16 & 18.89 & 15.04 \\
\hline Initial return & 0.10 & 0.06 & 0.11 & 0.07 \\
\hline Size (m) & 4789 & 3730 & 4597 & 3676 \\
\hline Proceeds (m) & 1968 & 1085 & 1949 & 1074 \\
\hline Pre-IPO sales (m) & 4940 & 4228 & 4841 & 4144 \\
\hline Pre-IPO net profits & 388 & 245 & 376 & 237 \\
\hline No of obs. & 202 & & 127 & \\
\hline
\end{tabular}


Table VII continued

\begin{tabular}{|c|c|c|c|c|c|c|}
\hline \multirow{2}{*}{$\begin{array}{l}\text { Panel C } \\
\text { AFT Analysis } \\
\text { based on matched sample }\end{array}$} & \multicolumn{2}{|c|}{ Model I (M\&A as Failures) } & \multicolumn{2}{|c|}{ Model II (M\&A as Censored Survival) } & \multicolumn{2}{|c|}{ Model III (M\&A as Failures) } \\
\hline & Coefficient & Time-ratio & Coefficient & Time-ratio & Coefficient & Time-ratio \\
\hline Strategic investor & $0.544 * * *$ & 1.723 & $0.374 * *$ & 1.454 & $0.1446^{* *}$ & 1.1556 \\
\hline Cornerstone investor & 0.097 & 1.102 & 0.184 & 1.202 & 0.1679 & 1.1828 \\
\hline Inverse mills (Strategic) & & & & & -0.1116 & 0.8944 \\
\hline Inverse mills (Cornerstone) & & & & & 0.1829 & 1.2922 \\
\hline Demand multiple & $0.169^{* *}$ & 1.184 & $0.048 *$ & 1.049 & 0.0599 & 1.0617 \\
\hline Insider ownership & $0.220 * *$ & 1.246 & $0.346^{* *}$ & 1.413 & $0.2300^{*}$ & 1.2586 \\
\hline Family control & 0.050 & 1.052 & 0.038 & 1.039 & 0.1550 & 1.1676 \\
\hline Instit. allocation & $0.283 * *$ & 1.327 & $0.305^{* *}$ & 1.357 & 0.2529 & 1.2877 \\
\hline Age & 0.033 & 1.034 & 0.124 & 1.132 & 0.0116 & 1.0117 \\
\hline Size & $0.064^{* *}$ & 1.066 & $0.083^{* *}$ & 1.087 & $0.0627 *$ & 1.0647 \\
\hline Initial return & 0.141 & 1.151 & 0.139 & 1.149 & 0.2532 & 1.2882 \\
\hline Proceeds & $0.066^{* *}$ & 1.068 & $0.089^{* *}$ & 1.093 & $0.0263 *$ & 1.0267 \\
\hline Pre-IPO net profits & 0.028 & 1.028 & $0.075^{*}$ & 1.078 & 0.1234 & 1.1313 \\
\hline Pre-IPO sales & 0.024 & 1.025 & $0.104^{*}$ & 1.110 & 0.0084 & 1.0084 \\
\hline H-shares & 0.103 & 1.108 & 0.144 & 1.155 & 0.1925 & 1.2122 \\
\hline Reputable underwriter & 0.059 & 1.061 & 0.062 & 1.064 & 0.0234 & 1.0236 \\
\hline Industry & $\mathrm{Y}$ & & $\mathrm{Y}$ & & $\mathrm{Y}$ & \\
\hline Year & $\mathrm{Y}$ & & $\mathrm{Y}$ & & $\mathrm{Y}$ & \\
\hline Constant & -0.451 & & -0.534 & & -0.2245 & \\
\hline Pseudo R-square & 0.12 & & 0.11 & & 0.085 & \\
\hline No of obs. & 618 & & 618 & & 381 & \\
\hline
\end{tabular}




\section{Appendix Table I: Definition of Variables}

\begin{tabular}{|c|c|c|}
\hline Variable & Definition of variable and unit of measurement & Data source \\
\hline $\begin{array}{l}\text { Strategic investors/ } \\
\text { Cornerstone investors }\end{array}$ & $\begin{array}{l}\text { The involvement and commitment of strategic investors, and } \\
\text { separately of cornerstone investors, are measured by five } \\
\text { alternate indicators: (i) a binary indicator (coded one if the } \\
\text { given investor type is involved in an IPO and zero otherwise); } \\
\text { (ii) the average lock-up period of these investors in an IPO; (iii) } \\
\text { the numbers of these investors involved in an IPO; (Iv) the ratio } \\
\text { of foreign to locally-based investors and (v) the proportion of } \\
\text { shares in an IPO allocated to these investors. }\end{array}$ & $\begin{array}{l}\text { IPO prospectus (cross- } \\
\text { referenced with } \\
\text { allotment/allocation data } \\
\text { from Hong Kong Stock } \\
\text { Exchange) }\end{array}$ \\
\hline $\begin{array}{l}\text { Institutional } \\
\text { allocations }\end{array}$ & $\begin{array}{l}\text { Proportion of shares allocated to institutional investors at the } \\
\text { time of an IPO. }\end{array}$ & $\begin{array}{l}\text { Allotment/allocation data } \\
\text { from Hong Kong Stock } \\
\text { Exchange }\end{array}$ \\
\hline Demand multiple & $\begin{array}{l}\text { Oversubscription for shares at the time of the IPO. It is } \\
\text { calculated as the total number of shares applied for, deflated by } \\
\text { the total number of shares offered. }\end{array}$ & $\begin{array}{l}\text { Allotment/allocation data } \\
\text { from Hong Kong Stock } \\
\text { Exchange }\end{array}$ \\
\hline Insider ownership & Percentage of insider ownership at the time of IPO completion. & IPO prospectus \\
\hline Size & $\begin{array}{l}\text { Market capitalization at IPO: number of shares outstanding at } \\
\text { IPO times initial offer price measured in } \mathrm{HK} \$ \text { millions. }\end{array}$ & IPO prospectus \\
\hline Age & Number of years between incorporation and IPO date. & IPO prospectus \\
\hline Initial return & $\begin{array}{l}\text { First-day closing price minus offer price divided by offer price; } \\
\text { as a percentage. }\end{array}$ & IPO prospectus. \\
\hline Proceeds & Money raised at the IPO; issue proceeds. & IPO prospectus \\
\hline Pre-IPO sales & Sales in the year prior to and the year of the IPO: years -1 to 0 . & IPO prospectus \\
\hline Pre-IPO net profits & $\begin{array}{l}\text { Operating income in the year prior to and the year of the IPO: } \\
\text { years }-1 \text { to } 0 .\end{array}$ & IPO prospectus \\
\hline Family & $\begin{array}{l}\text { A binary variable equal to } 1 \text { if the IPO is family controlled, and } \\
\text { zero otherwise. }\end{array}$ & IPO prospectus \\
\hline H Share & $\begin{array}{l}\text { A binary variable equal to } 1 \text { if the IPO is incorporated in China, } \\
\text { and zero otherwise. }\end{array}$ & IPO prospectus \\
\hline
\end{tabular}


Appendix Table I continued

Reputable underwriter A binary variable taking a value of 1 if an IPO is underwritten

Hong Kong Stock Market by top underwriters and zero otherwise. Top underwriters are those in the top quartile in terms of both numbers and proceeds of IPOs they bring to the market during 3 years prior to the IPO year.

Industry

Industry dummies based on the Hong Kong Stock Exchange industry classification, indicating companies in the following categories:

- financial industry

- cyclical services

- information technology

- non-cyclical consumer goods

- resources

The industry class "Others" is used as the base category in the estimations. 


\section{Appendix Table II: Descriptive statistics for the full sample 1997-2010}

Instit. allocation is the proportion of shares in the IPO allocated to institutional shareholders. Demand multiple is the oversubscription rate for shares at the time of the IPO. Insider ownership is the percentage of insider ownership at the time of the IPO. Family control is a dummy variable taking a value of one if the IPO firm is family controlled and zero otherwise. Age is the number of years from establishment until the IPO. Initial return is the difference between the first-day closing and offer prices as a percentage of the offer price. Size is market capitalization at the IPO price (in million Hong Kong dollars). Proceeds is IPO proceeds in million Hong Kong dollars. Pre-IPO sales is sales before the year of the IPO. Pre-IPO net profits is the operating income in the year before the year of the IPO. H-share is a dummy variable that equals 1 if the IPO firm is incorporated in mainland China but listed in Hong Kong and zero otherwise. Reputable underwriter is a dummy variable taking a value of 1 if an IPO is underwritten by reputable underwriters as measured by the number of IPOs and proceeds, and zero otherwise.

\begin{tabular}{lrrrrr}
\hline Full sample & \multicolumn{1}{c}{ Mean } & Median & \multicolumn{1}{c}{ STD } & Min & Max \\
& & & & & \\
\hline Instit. allocation & 0.560 & 0.720 & 0.401 & 0.000 & 0.920 \\
Demand multiple & 84.420 & 21.330 & 164.220 & 0.760 & 789.290 \\
Insider ownership & 0.711 & 0.701 & 0.054 & 0.520 & 0.870 \\
Family control (binary) & 0.411 & 0.000 & 0.492 & 0.000 & 1.000 \\
Age & 17.000 & 13.000 & 12.110 & 4.800 & 58.000 \\
Initial return & 0.130 & 0.070 & 0.220 & -0.110 & 0.880 \\
Size (m) & 5310.23 & 3472.85 & 6963.34 & 181 & 26100 \\
Proceeds (m) & 2247.62 & 1419.63 & 2304.21 & 50 & 6520 \\
Pre-IPO sales (m) & 4904.35 & 4222.63 & 3100.15 & 94.78 & 9238.00 \\
Pre-IPO net profits (m) & 441.77 & 271.67 & 122.41 & 19.78 & 1127.66 \\
H-Share dummy & 0.142 & 0.000 & 0.340 & 0.000 & 1.000 \\
Reputable underwriter & 0.149 & 0.000 & 0.411 & 0.000 & 1.000 \\
No of obs & $\mathbf{6 0 7}$ & & & & \\
\hline
\end{tabular}




\section{Appendix Table III: Descriptive statistics for IPOs without strategic or cornerstone investors 1997-2010}

Instit. allocation is the proportion of shares in the IPO allocated to institutional shareholders. Demand multiple is the oversubscription rate for shares at the time of the IPO. Insider ownership is the percentage of insider ownership at the time of the IPO. Family control is a dummy variable taking a value of one if the IPO firm is family controlled and zero otherwise. Age is the number of years from establishment until the IPO. Initial return is the difference between the first-day closing and offer prices as a percentage of the offer price. Size is market capitalization at the IPO price (in million Hong Kong dollars). Proceeds is IPO proceeds in million Hong Kong dollars. Pre-IPO sales is sales before the year of the IPO. Pre-IPO net profits is the operating income in the year before the year of the IPO. $H$-share is a dummy variable that equals 1 if the IPO firm is incorporated in mainland China but listed in Hong Kong and zero otherwise. Reputable underwriter is a dummy variable taking a value of 1 if an IPO is underwritten by reputable underwriters as measured by the number of IPOs and proceeds, and zero otherwise.

\begin{tabular}{lrrrrr}
\hline $\begin{array}{l}\text { IPOs without strategic or cornerstone } \\
\text { investors (1997-2010) }\end{array}$ & \multicolumn{1}{c}{ Mean } & \multicolumn{1}{l}{ Median } & \multicolumn{1}{c}{ STD } & Min & Max \\
\hline Instit. allocation & 0.41 & 1.03 & 0.58 & 0.00 & 0.82 \\
Demand multiple & 57.03 & 6.50 & 207.51 & 0.76 & 789.29 \\
Insider ownership & 0.60 & 0.57 & 0.04 & 0.52 & 0.79 \\
Family control (binary) & 0.56 & 0.00 & 0.75 & 0.00 & 1.00 \\
Age & 13.47 & 9.53 & 9.31 & 4.8 & 43.64 \\
Initial return & 0.10 & 0.03 & 0.25 & -0.20 & 0.88 \\
Size (m) & 4642.61 & 2203.64 & 5429.23 & 181 & 20114.15 \\
Proceeds (m) & 2331.07 & 1659.19 & 2568.79 & 50 & 5762.62 \\
Pre-IPO sales (m) & 4521.77 & 3810.96 & 3199.97 & 829.24 & 8323.69 \\
Pre-IPO net profits (m) & 516.72 & 358.15 & 289.65 & 268.80 & 1127.66 \\
H-Share dummy & 0.09 & 0.00 & 0.27 & 0.00 & 1.00 \\
Reputable underwriter & 0.08 & 0.00 & 0.49 & 0.00 & 1.00 \\
No of $\boldsymbol{o b s}$ & $\mathbf{2 2 6}$ & & & & \\
\hline
\end{tabular}




\section{Appendix Table IV: AFT results (M\&A are failures) (1997-2010)}

This table shows the results of the AFT model (with M\&A delistings regarded as failures) using alternate measures of cornerstone and strategic investors: Strategic/Cornerstone investors is measured as a binary variable in Model I, as their average lock-up periods in Model II, as the number of investors in Model III, as the ratio of foreign cornerstone investors to local ones in Model IV and as the proportion of shares allocated in Model V. Demand multiple is the oversubscription rate for shares at the time of the IPO. Insider ownership is the percentage of insider ownership at the time of the IPO. Family control is a dummy variable taking a value of one if the IPO firm is family controlled and zero otherwise. Instit. Allocation is the proportion of shares in the IPO allocated to institutional investors. Age is the number of years from establishment until the IPO. Size is the logarithm of logarithm of the market capitalization at the offer price. Initial return is the difference between the first-day closing and offer price as a percentage of the offer price. Proceeds is IPO proceeds in million Hong Kong dollars. Pre-IPO net profits is the operating income in the year before the year of the IPO. Pre-IPO sales is sales before the year of the IPO. H-share is a dummy variable that equals 1 if the IPO firm is incorporated in mainland China but listed in Hong Kong and zero otherwise. Reputable underwriter is a dummy variable taking a value of 1 if an IPO is underwritten by reputable underwriters as measured by the number of IPOs and proceeds, and zero otherwise. We control for year and industry in the regressions. ***, **, and $*$ indicate significance at $1 \%, 5 \%$, and $10 \%$ respectively.

\begin{tabular}{|c|c|c|c|c|c|c|c|c|c|c|}
\hline \multirow[t]{2}{*}{ M\&As as failures } & \multicolumn{2}{|c|}{$\begin{array}{l}\text { Model I } \\
\text { Binary }\end{array}$} & \multicolumn{2}{|c|}{$\begin{array}{l}\text { Model II } \\
\text { Lock-up }\end{array}$} & \multicolumn{2}{|c|}{$\begin{array}{l}\text { Model III } \\
\text { Number }\end{array}$} & \multicolumn{2}{|c|}{$\begin{array}{c}\text { Model IV } \\
\text { Foreign-local }\end{array}$} & \multicolumn{2}{|c|}{$\begin{array}{c}\text { Model V } \\
\text { Allocations } \\
\end{array}$} \\
\hline & Coeff & TR & Coeff & TR & Coeff & TR & Coeff & TR & Coeff & TR \\
\hline $\begin{array}{l}\text { Strategic investor } \\
\text { Cornerstone }\end{array}$ & $0.284 * * *$ & 1.328 & $0.298 * * *$ & 1.347 & $0.400 * * *$ & 1.491 & $0.537 * * *$ & 1.710 & $0.242 *$ & 1.274 \\
\hline investor & 0.159 & 1.172 & 0.062 & 1.064 & 0.053 & 1.054 & 0.148 & 1.159 & 0.172 & 1.188 \\
\hline Demand multiple & 0.086 & 1.090 & $0.161 * *$ & 1.174 & $0.154 * *$ & 1.167 & $0.164 * *$ & 1.178 & $0.150 * *$ & 1.162 \\
\hline Insider ownership & $0.187^{*}$ & 1.205 & $0.069 *$ & 1.071 & $0.066^{*}$ & 1.068 & $0.052 *$ & 1.053 & $0.062 *$ & 1.064 \\
\hline Family control & $0.232 *$ & 1.261 & $0.436 * *$ & 1.547 & $0.422 * *$ & 1.526 & $0.212 * *$ & 1.236 & $0.219 * *$ & 1.245 \\
\hline Instit. allocation & 0.300 & 1.350 & $0.215^{* *}$ & 1.240 & $0.220 * *$ & 1.246 & 0.233 & 1.262 & $0.216^{* *}$ & 1.241 \\
\hline Age & $0.087 *$ & 1.091 & 0.032 & 1.033 & 0.038 & 1.039 & 0.014 & 1.014 & 0.012 & 1.012 \\
\hline Size & $0.091 * *$ & 1.096 & $0.034 * *$ & 1.035 & $0.032 * *$ & 1.032 & $0.030 * *$ & 1.030 & $0.030 * *$ & 1.031 \\
\hline Initial return & $0.200 *$ & 1.222 & 0.187 & 1.206 & 0.093 & 1.097 & 0.034 & 1.034 & 0.047 & 1.048 \\
\hline Proceeds & $0.085 * *$ & 1.088 & $0.034 * *$ & 1.035 & $0.032 * *$ & 1.032 & $0.030 * *$ & 1.031 & $0.031 * *$ & 1.031 \\
\hline Pre-IPO net profits & 0.032 & 1.032 & 0.042 & 1.043 & 0.044 & 1.045 & 0.047 & 1.048 & 0.045 & 1.046 \\
\hline Pre-IPO sales & 0.038 & 1.038 & 0.068 & 1.071 & 0.050 & 1.052 & 0.047 & 1.048 & 0.014 & 1.014 \\
\hline H-shares & 0.098 & 1.103 & 0.0269 & 1.026 & 0.026 & 1.027 & 0.015 & 1.015 & 0.017 & 1.017 \\
\hline Reput underwriter & $0.109 * *$ & 1.116 & 0.021 & 1.021 & 0.014 & 1.014 & 0.085 & 1.089 & $0.091 *$ & 1.095 \\
\hline Industry & $\mathrm{Y}$ & & $\mathrm{Y}$ & & $\mathrm{Y}$ & & $\mathrm{Y}$ & & $\mathrm{Y}$ & \\
\hline Year & $\mathrm{Y}$ & & $\mathrm{Y}$ & & $\mathrm{Y}$ & & $\mathrm{Y}$ & & $\mathrm{Y}$ & \\
\hline Constant & -0.611 & & 0.877 & & 0.881 & & 1.512 & & 1.387 & \\
\hline Pseudo R-square & 0.122 & & 0.151 & & 0.147 & & 0.161 & & 0.171 & \\
\hline No of obs. & 607 & & 607 & & 607 & & 607 & & 607 & \\
\hline
\end{tabular}




\section{Appendix Table V: Correlation matrix}

\begin{tabular}{|c|c|c|c|c|c|c|c|c|c|c|c|c|c|}
\hline Variables & & $(1)$ & $(2)$ & $(3)$ & $(4)$ & $(5)$ & $(6)$ & $(7)$ & $(8)$ & $(9)$ & $(10)$ & $(11)$ & $(12)$ \\
\hline $\begin{array}{l}\text { Demand for } \\
\text { subscription }\end{array}$ & (1) & 1 & & & & & & & & & & & \\
\hline Insider ownership & (2) & -0.0855 & 1 & & & & & & & & & & \\
\hline Family control & (3) & -0.0064 & 0.0122 & 1 & & & & & & & & & \\
\hline Instit. allocation & (4) & -0.1071 & 0.0156 & 0.0143 & 1 & & & & & & & & \\
\hline Age & (5) & 0.0338 & -0.0137 & -0.0683 & -0.0759 & 1 & & & & & & & \\
\hline Initial return & (6) & 0.4102 & -0.0309 & 0.011 & -0.1949 & 0.0647 & 1 & & & & & & \\
\hline Size & (7) & -0.0442 & 0.2031 & -0.0156 & 0.2105 & 0.0319 & -0.0525 & 1 & & & & & \\
\hline Proceeds & $(8)$ & -0.0335 & 0.0996 & -0.0095 & 0.24 & 0.0125 & -0.0494 & 0.4484 & 1 & & & & \\
\hline Pre-IPO net profits & $(9)$ & -0.0269 & 0.1467 & -0.1069 & 0.0827 & 0.0275 & -0.0174 & 0.1867 & 0.1205 & 1 & & & \\
\hline Pre-IPO sales & (10) & -0.0413 & 0.0802 & -0.1135 & 0.1052 & 0.0425 & -0.0416 & 0.2094 & 0.054 & 0.4138 & 1 & & \\
\hline H-shares & (11) & 0.0397 & -0.0566 & -0.0288 & 0.0649 & -0.0191 & 0.0342 & 0.0991 & 0.0589 & 0.0041 & 0.0304 & 1 & \\
\hline Reputable underwriter & (12) & 0.096 & -0.0363 & -0.1367 & -0.2038 & 0.0027 & 0.1088 & -0.0249 & -0.0121 & -0.0484 & -0.0396 & -0.0343 & 1 \\
\hline
\end{tabular}

